\section{AATS Aortic Symposium 2016}

May 12-13, 2016

Sheraton New York Times Square Hotel

New York, NY, USA

\author{
Abstract \& Video Submission Deadline: \\ Monday, December 14, 2015, by 11:59 PM EST \\ Course Directors: \\ Joseph S. Coselli \\ Steven L. Lansman \\ Co-Directors: \\ Joseph E. Bavaria \\ Nicholas T. Kouchoukos \\ G. Chad Hughes \\ David Spielvogel \\ Thoralf M. Sundt \\ Lars G. Svensson
}

\section{SUBMISSION OF ABSTRACTS \& VIDEOS}

The AATS welcomes you to submit your Abstracts and Videos to the Aortic Symposium 2016. Specific instructions for abstract and video submission are located on our Web site at www.aats.org/aortic.

Investigators are invited to submit original work to include BOTH of the following:

- Abstract (maximum of 200 words), accompanied by

- PowerPoint presentation of the material (maximum of 12 slides)

OR

- Abstract(maximum of 200 words), accompanied by

- Video (maximum of 5 minutes, for the Presentation On Demand (POD) system ONLY and must be narrated in English)

Submit your abstract online at www.aats.org/aortic.

\section{The AATS Graham Foundation} Available AATS Graham Foundation Awards

Applications Open: James L. Cox Fellowship in Atrial Fibrillation Surgery

The AATS Graham Foundation invites applications for the James L. Cox Fellowship in Atrial Fibrillation sponsored by Atricure.

\begin{abstract}
About
The fellowship gives newly graduated CT surgeons the ability to spend up to three months improving their atrial fibrillation techniques at a host institution. This hands-on immersive experience allows awardees to enhance their clinical understanding and surgical proficiency in the treatment of atrial fibrillation under the tutelage of top surgeon educators. Successful applicants will receive a $\$ 15,000$ stipend to help offset their living expenses.
\end{abstract}

Deadline: September 1, 2015

More information: http://aatsgrahamfoundation.org/awards_ atricure.cgi
Travel Awards: AATS Cardiovascular Symposium Brazil

Eligible physicians from Central and South America are invited to apply for travel awards to the AATS Cardiovascular Symposium Brazil-part of the Edwards Lifesciences Foundation Every Heartbeat Matters initiative.

November 20-21, 2015

Renaissance Marriot São Paolo

São Paolo, Brazil

About

Awards of $\$ 1,000$ will be available to physicians who currently are treating underserved populations with valve disease and will be doing so in the future. Applicant must demonstrate financial need. Applicants must provide information on the role they are presently playing in treating underserved populations and how the symposium will help them expand their patient base.

Deadline: September 1, 2015

More information: http://aatsgrahamfoundation.org/

Visit the WTSA Web site at www.westernthoracic.org to read the complete membership eligibility requirements and to initiate an online application.

\section{Applications for Membership}

The WTSA is now accepting Applications for Membership online for Active as well as Candidate membership status.
Active Member

$\$ 325.00$ annually, plus $\$ 50.00$ initiation fee 
Applicant must meet all membership criteria, including but not limited to:

- Reside within or have completed a cardiothoracic residency training program within the geographic limits of the Association.

- Have been engaged in the practice of thoracic and cardiovascular surgery for at least three years following completion of postgraduate training. If a candidate completed his/her thoracic surgical residency or a one-year clinical fellowship in an institution within the geographic limits of the Association, such completion may count towards one of the three years of practice.

- Have a full and unrestricted license to practice medicine in his or her respective state or province, and have a current appointment on the surgical staff of a hospital with no reportable action pending which could adversely affect such applicant's staff privileges at any hospital.

\section{Candidate Member}

$\$ 100.00$ annually

Applicant must meet all membership criteria, including but not limited to:

- Be matched or enrolled in either a cardiothoracic surgery education program accredited by the Residency Review Committee for Thoracic Surgery under the authority of the ACGME or a program approved for cardiothoracic surgery education by the Royal College of

\section{The American Board of Thoracic Surgery}

\section{ABTS Announcement}

The American Board of Thoracic Surgery's Maintenance of Certification program was adopted 7 years ago. Since that time, there has been a continuous evaluation in the Board's thinking about the overall process, based upon internal discussions and input from our diplomates.

These inputs resulted in our decision to migrate from a purely knowledge-based multiple-choice exam, using a Pearson Testing Center, to a Mastery Learning Process, using a SESATS format. Diplomates, enrolled in this year's (2015) 10-year MOC process, will fulfill their Part III requirement by completion of a home or office-based secure learning exam, following the instructions on the ABTS Web site.

In brief, you will be directed to a secure Web site, administered by Software Secure. The only special computer hardware needed will be a camera for your home or office computer (most laptops now come with a built-in camera). Once logged in, you will be asked to verify your identity
Surgeons of Canada-or their equivalency-from within the Association's geographic limits. Individuals who have completed their education in one of the above programs and are in the process of acquiring certification in cardiothoracic surgery by either the American Board of Thoracic Surgery or the Royal College of Surgeons of Canada also are eligible to apply for Candidate membership. Individuals who trained outside the Association's geographic limits who are now residing within the Association's boundaries but do not yet have three years in practice may also apply for Candidate membership.

An application must include the following uploads: a photo; a complete curriculum vitae with bibliography; and, for Active applicants, the 3 most significant articles that s/he personally wrote. The application must be completed and submitted online by March 1, 2016, and all support letter(s) (three for Active applicants, one for Candidates) uploaded by that applicant's sponsor(s) by March 31, 2016, in order for the applicant to be considered for election to membership at the 2016 Annual Meeting.

\section{WTSA 42nd Annual Meeting}

\author{
Save the Date! \\ June 22-25, 2016 \\ Hilton Waikoloa Village \\ Waikoloa, Hawaii
}

by holding up your driver's license with your picture next to your face. You will be visually monitored for the time you are logged onto the Web site.

There are 100 SESATS questions (primarily taken from SESATS X), based on your specialty designation (Adult Cardiac, General Thoracic, Cardiothoracic, and Congenital), that you will need to work through as instructed. The exam will now be modular and tailored to your practice-for example, if your practice is $100 \%$ adult cardiac, you will only have adult cardiac and critical care questions. You will have 15 hours with as many as 10 logins to complete the 100 questions during the months of September and October 2015. For those diplomates who have used SESATS in the past, the process of working through the questions is the same. For those who aren't familiar with SESATS, it might be beneficial to purchase and download SESATS $X$ and work through the specialty-specific module. This preparation will give you familiarity with the process. While SESATS X may be helpful preparation, it is not required.

The goal of this exam is to provide a learning opportunity using judgement and decision making as well as knowledge. There is no grade involved, but you will be given 